\title{
Pre- versus postnatal initial colonization of healthy neonates' colon ecosystem by the enterobacterium Escherichia coli
}

\author{
Mohammad Al-Balawi \\ Taibah University \\ Fatthy Morsy ( $\sim$ fmorsy@aun.edu.eg ) \\ Taibah University
}

\section{Research Article}

Keywords: colon bacteria, Escherichia coli, healthy neonates, meconium, postnatal, prenatal

Posted Date: February 26th, 2021

DOl: https://doi.org/10.21203/rs.3.rs-242240/v1

License: (c) (1) This work is licensed under a Creative Commons Attribution 4.0 International License.

Read Full License 


\section{Abstract \\ Background}

Human colon is a microbial ecosystem where its initial bacterial colonization in neonates is important step for establishing a beneficial microbiota for the body health. This study investigated occurrence of viable culturable Escherichia coli in first day meconium versus subsequent days stool to explore the prenatal versus postnatal initial colonization of colon by Escherichia coli in healthy neonates.

\section{Methods}

E. coli occurrence was conducted on eosin methylene blue agar followed by morphological and biochemical characterizations and phylogenetic analysis of 16S rRNA encoding gene.

\section{Results}

Viable culturable $E$. coli was not detected in meconium of healthy male and female neonates of normal birth or cesarean section surgical delivery. Neonates of surgical delivery showed no $E$. coli colonization at also 2 nd and 3rd day confirming a postnatal colonization of colon by this enterobacterium. E. coli initial colonization in colon of normal birth neonates occur at 2nd day which can be attributed to inoculation from vaginal canal during delivery which in comparison to neonates of surgical delivery infers that the bacterium is not originally found in meconium.

\section{Conclusions}

This study suggests no viability of meconium microbiome in healthy neonates possibly due to antimicrobial action in the prenatal colon's meconium protecting babies' gut from infection during delivery.

\section{Introduction}

The human colon as a microbial ecosystem retains a microbial community playing important roles for body health [1-8]. The initial colonization of the colon by bacteria is important in formulating the microbial community where this initial bacterial colonization is a complicated process in correlation with some factors that might affect the establishment of the microbiome within the colon of the neonate [911]. The origin of the bacterial inoculation for establishment of the colon microbiome is mostly expected to be postnatal while the colon is sterile prenatal. However; bacterial DNA was detected in the first-pass meconium and a meconium microbiome was reasonably reported [12-18]. Thus, the colonization of human gut was suggested to initiate prenatal in utero where inoculation might reasonably occur from Loading [MathJax]/jax/output/CommonHTML/jax.js ita and amniotic fluid [19, 20] where human uterine 
microbiome was reported in even non-pregnant women [21]. These reports largely based on direct sample DNA extraction and subsequent molecular biological identifications and analysis. Despite the detection of some bacteria in a culture dependent approach, the microbiome of the placenta, amniotic fluid and meconium studied by molecular biological tools was concluded to be with low richness and diversity [19].

E. coli is a basic member of the colon microbial community [22-25] and is an indicator of the fecal microflora [26]. In spite of its frequent pathogenicity, E. coli as one of the normal microflora in the human gut plays several important roles for human health [27]. E. coli was suggested to play an important role to sustain the fermentation processes in the colon. Fermentation occurs in the human colon which retains hundreds of different bacterial species $[10,11,28-30]$ where the fermentation processes and the bacterial colonization of the colon are of importance to the human health in many aspects [10,11]. The relationships between different components of the colon bacteria are not fully understood. Fermentative micro-aerophilic and anaerobic bacteria found in the colon would require installation and maintenance of anaerobiosis within the colon. Micro-aerophilic and anaerobic bacteria colonize the neonates' large intestine [31, 32] which would require installation of anaerobic conditions favored by such health beneficial bacteria. The occurrence of $E$. coli at the early stage of human life might reveal its importance for the body development after birth and a possible way by which installation of anaerobiosis occurs for setting up favorable conditions for colonization by micro-aerophilic and anaerobic health beneficial bacteria. E. coli as a facultative anaerobe that can consume molecular oxygen can help in installing the microaerobic or anaerobic conditions required for beneficial micro and anaerobic bacteria in the colon such as Lactobacillus sp and others. While colonization of the human colon by $E$. coli and other bacteria varies according to the mode of delivery [33], type of feeding and several other factors [6,34-36], the recently proposed prenatal versus the postnatal initial colonization should be explored for this important fundamental bacterial member of the human colon microbiome. In this study we followed the occurrence of viable culturable $E$. coli as a basic member of the Enterobacteriaceae in the first day meconium and subsequent days stool samples to follow up its viable initial colonization of colon in of healthy neonates.

\section{Results}

In this study the postnatal versus prenatal initial colonization of colon by enterobacterium E. coli was followed through following its occurrence in first pass meconium and subsequent days stool of healthy newborn babies. E. coli was not detected in first day meconium of all newborn babies investigated in this study (Table 1). E. coli was not detected at all in the 2 nd and 3rd day stool samples of all newborn babies of cesarean section surgical delivery either in male or female babies (Table 1) while its occurrence initiated at 4th day (Fig. 1C and 1D). These results indicate that E. coli colonization of colon is postnatal as clearly shown in case of cesarean section surgical delivery newborn male and female babies. While, $E$. coli occurrence initiated at 2nd day stool of normal birth male and female babies (Fig. 1A and 1B), it was not present in 20 to $60 \%$ of babies subjects up to 4 th day (Table 1 ) where subsequently at 5 th day all neonates' subjects retained the bacterium. The absence of $E$. coli in meconium and its appearance in only 20 to $60 \%$ of normal birth babies, do not support a prenatal inoculation but confirm the same conclusion 
of postnatal initial colonization clearly appeared in case of cesarean section surgical delivery neonates. Inoculation from the surrounding environment after birth such as feeding process and others either in case of normal birth or surgical delivery by cesarean section is highly possible. Inoculation from the surrounding environment after birth such as feeding process and others either in case of normal birth or surgical delivery by cesarean section is highly possible. The early appearance of $E$. coli in normal birth neonates' colon can be attributed to an additional source of inoculation through vaginal canal during delivery process in addition to the inoculation from the surrounding environment. For confirmed identification, phylogenetic analysis of 16S rRNA encoding gene was conducted for $E$. colistrains isolated from male neonates of normal birth (Fig. 2), female neonates of normal birth (Fig. 3), male neonates of surgical delivery by cesarean section (Fig. 4) and female neonates of surgical delivery by cesarean section (Fig. 5). All strains were identified as E. coli by the phylogenetic analysis of the $16 \mathrm{~S}$ rRNA encoding gene sequence (Fig. 2 to 5). Although E. coli appeared in normal birth babies' stool earlier than in that of newborn babies of cesarean section surgical delivery, CFU of the bacterium in both mode of delivery were comparable in 5th and 6th day ranging from $\left(38.4 \times 10^{6}\right)$ to $\left(44 \times 10^{6}\right)$ in 5 th day age and from $\left(49 \times 10^{6}\right)$ to $\left(56.6 \times 10^{6}\right)$ in 6 th day age $($ Table 1$)$. Thus, while E. coli colonized no baby of cesarean section surgical delivery neither male nor female up to babies of 3 days old, the bacterium sharply colonized the babies at 4th day old babies and the CFU was almost comparable to that of normal birth at 5th and 6th day old (Fig. 1). These results indicate sharper log phase of the bacterium colonization after inoculation from surrounding environment of newborn babies of cesarean section surgical delivery. This might be attributed to the more space for colonization due to late inoculation and to possibly more suitability of colonization condition at this age of 5 and 6 days old. The results presented in this study indicate postnatal colonization of $E$. coli to colon of newborn babies whatever the type of mode of delivery or the babies gender either male or female. 
Table 1

Colony forming units (CFU $\times 10^{6}$ per gram stool) of Escherichia coli in first day meconium and subsequent days stool of neonates at first week of their life.

\begin{tabular}{|c|c|c|c|c|c|}
\hline \multirow[t]{2}{*}{ Age } & \multirow[t]{2}{*}{ Neonates subject No. } & \multicolumn{2}{|c|}{ Normal birth } & \multicolumn{2}{|c|}{ Caesarean section } \\
\hline & & Male & Female & Male & Female \\
\hline 1 & 1 & $N D^{a}$ & ND & ND & ND \\
\hline \multirow[t]{4}{*}{ First-pass meconium } & 2 & ND & ND & ND & ND \\
\hline & 3 & ND & ND & ND & ND \\
\hline & 4 & ND & ND & ND & ND \\
\hline & 5 & ND & ND & ND & ND \\
\hline \multirow[t]{7}{*}{2} & 1 & ND & ND & ND & ND \\
\hline & 2 & 8 & 8 & ND & ND \\
\hline & 3 & ND & ND & ND & ND \\
\hline & 4 & 33 & 14 & ND & ND \\
\hline & 5 & 29 & 32 & ND & ND \\
\hline & Mean & 14 & 10.8 & 0 & 0 \\
\hline & $S E^{b}$ & 7.1 & 5.9 & 0 & 0 \\
\hline \multirow[t]{7}{*}{3} & 1 & ND & ND & ND & ND \\
\hline & 2 & 4 & ND & ND & ND \\
\hline & 3 & 51 & 9 & ND & ND \\
\hline & 4 & 17 & 18 & ND & ND \\
\hline & 5 & 9 & ND & ND & ND \\
\hline & Mean & 16.2 & 5.4 & 0 & 0 \\
\hline & SE & 9.2 & 3.6 & 0 & 0 \\
\hline \multirow[t]{3}{*}{4} & 1 & ND & ND & ND & 11 \\
\hline & 2 & ND & 35 & 20 & ND \\
\hline & 3 & ND & 22 & 31 & ND \\
\hline 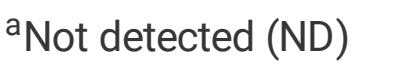 & & & & & \\
\hline
\end{tabular}




\begin{tabular}{|c|c|c|c|c|c|}
\hline & 4 & 28 & 13 & 39 & 49 \\
\hline & 5 & 14 & 25 & 14 & 26 \\
\hline & Mean & 8.4 & 19 & 20.8 & 17.2 \\
\hline & SE & 5.6 & 5.9 & 6.8 & 9.3 \\
\hline \multirow[t]{7}{*}{5} & 1 & 32 & 24 & 32 & 37 \\
\hline & 2 & 41 & 38 & 34 & 53 \\
\hline & 3 & 53 & 49 & 46 & 38 \\
\hline & 4 & 48 & 51 & 38 & 47 \\
\hline & 5 & 46 & 48 & 42 & 43 \\
\hline & Mean & 44 & 42 & 38.4 & 43.6 \\
\hline & SE & 3.6 & 5 & 2.6 & 3 \\
\hline \multirow[t]{7}{*}{6} & 1 & 41 & 41 & 51 & 29 \\
\hline & 2 & 62 & 54 & 67 & 45 \\
\hline & 3 & 68 & 59 & 44 & 59 \\
\hline & 4 & 53 & 50 & 47 & 49 \\
\hline & 5 & 59 & 63 & 56 & 63 \\
\hline & Mean & 56.6 & 53.4 & 53 & 49 \\
\hline & SE & 4.6 & 3.8 & 4 & 6 \\
\hline \multicolumn{6}{|c|}{ 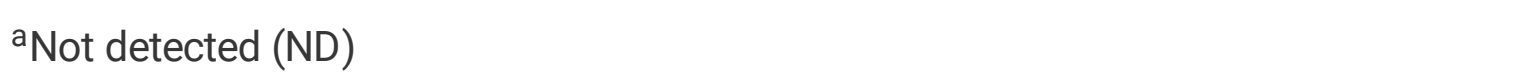 } \\
\hline & & & & & \\
\hline
\end{tabular}

\section{Discussion}

The initial bacterial colonization of neonates' colon is important and complicated process for a successful establishment of the beneficial bacteria in the neonate' colon $[9,44,45]$. In this study, the occurrence of $E$. coli was followed in first-pass meconium and subsequent days stool samples of healthy newborn babies to explore the pre- or postnatal initial colonization of their colon by E. coli.

Despite several reports presenting a microbiome in placenta, amniotic fluid and meconium, the viability and function of these microbiomes is not fully clear yet. The absence of viable culturable $E$. coli in the first-pass meconium in all investigated subjects and up to 3rd day in surgical delivery in this study, indicates that this bacterium which is a basic member of enterobacteria initiate colonization postnatal Loading [MathJax]/jax/output/CommonHTML/jax.js 
and that inoculation of the colon by this bacterium is hard to happen prenatal in uncomplicated pregnancies. The possibility of infection and bactericidal action against the bacterial infection in the uterine and in the prenatal colon meconium is likely to occur leaving a dead or static bacterial cells and hence bacterial DNA can be detected while these microbiomes might be non-viable ones. It was concluded that the fetal development proceeds in the absence of an amniotic fluid microbiota in uncomplicated pregnancies and the neonates' microbial colonization was thus predicted to begin after uterine contractions during delivery and rupture of amniotic membrane [46].

The human intestine is sterile at birth and the colonic function of the newborn babies is immature [47]. There was no E. coli detected in first pass meconium of newborn babies in all cases indicating no viable Enterobacteria is there before birth where inoculation occurs after birth possibly during vaginal delivery in case of normal birth or late inoculation from the surrounding environment including process of breast or formula feeding in case of cesarean section surgical delivery newborns neonates. While E. coli was detected in 2nd and 3rd day stool of normal birth male and female babies, it was not detected in such age of neither male nor female newborn babies of cesarean section surgical delivery. The early colonization of normal birth newborn babies' colon supports that inoculation by this bacterium occurs in addition to surrounding environment through the microbiota in the vagina canal which is known to retain E. coli [48] during the vaginal delivery process. It was reported that mothers showing different vaginal microbial communities shared different microorganisms with their newborns where this might reflect on the initial microbial colonizers of the developing newborn babies' gut [49]. The healthy vaginal microbiota play important role in newborn's health outcome where microbial community of infant's gut is shaped during birth, through delivery process that influence the gut initial assembly of its microbiota [50,51]. The appearance of $E$. coli from 2nd day in normal birth and 4th day in case of cesarean section surgical delivery newborns neonates indicates that this bacterium is postnatal colonizer of the human colon. Since all the babies subjects were selected in healthy status, the early colonization by $E$. coli strains identified in this study indicates a commensal status of these strains of the bacterium postnatal colonizing the colon. Despite the early appearance of $E$. coli in the stool of normal birth babies in comparison to that of newborn babies of cesarean section surgical delivery, there were comparable CFU mean numbers of the bacterium in both mode of delivery in 5-and 6-days old babies where there was a sharper log phase of the bacterium colonization for newborn babies of cesarean section surgical delivery upon inoculation indicating better suitability of the condition for colonization at this age. This also can be attributed to the more space for bacterial colonization in the newborn babies of cesarean section surgical delivery that was not inoculated yet by $E$. coli and possible other bacteria due to more sterile delivery mode of cesarean section surgery away from the bacterial flora of the vaginal canal. The bacterial colonization of colon in newborn babies of surgical delivery by cesarean section might occur through the feeding process either breast feeding or formula feeding. Several reports attributed the bacterial inoculation of newborn babies of surgical delivery by cesarean section through the feeding process [35]. This study showed that initial colonization by $E$. coli strains in the neonates' colon seems to be fundamentally occurring postnatal whatever the mode of delivery or gender of the newborn healthy bahies at the earlv stane firct week of their life. In spite of the early postnatal colonization of newborn Loading [MathJax]/jax/output/CommonHTML/jax.js 
babies' colon by $E$. coli detected in this study, a delay in colonization was detected in other studies where only $61 \%$ of the infants were positive by two months of age where many factors might affect the colonization [52].

One of the possible roles of the early postnatal colonization of $E$. coli as a basic member of the bacteria initially colonize the colon of newborn babies is its expected role in scavenging molecular oxygen gas for installing and maintaining micro and anaerobic conditions which is mandatory for the colon colonization by some micro and anaerobic beneficial bacteria widely detected in colon of healthy babies. Thus, E. coli might in addition to other facultative anaerobes act as initial servant bacterium which consumes molecular oxygen gas for installing anaerobiosis for colon colonization by microaerobic and anaerobic bacteria such as Lactobacilli. The Lactobacilli are of the initial colonizing bacteria of colon in healthy newborn babies [8]. Lactobacillus sp is usually found in babies colon where it plays important healthy roles $[53,54]$. Other beneficial anaerobes in neonates' colon would also require the anaerobic conditions that can be installed by the facultative anaerobic bacteria including $E$. coli consuming oxygen and permanently exist for such function of maintaining the suitable required micro and anaerobic conditions for viability of the beneficial micro and anaerobic bacteria. The consumption of oxygen by aerobic and facultative anaerobic bacteria along with other $\mathrm{O}_{2}$ consumption mechanisms in the human gut was suggested to maintain the gut lumen in a deeply anaerobic status which is important conditions for obligate anaerobes [55]. The vitamins known to be produced by $E$. coli such as vitamin $\mathrm{K}$ (menaquinone) [56-61] and vitamin B1 [62-65] might be important at this early stage starting from the first week of the babies' life possibly for a healthy body development. In spite of the pathogenicity of some $E$. colistrains $[66,67]$, this bacterium is a basic member of the human colon microbial community $[68,69]$ where many strains other than pathogenic ones were reported as commensal and some as health beneficial [70-75]. The initial colonization and early occupation of colon by $E$. coli strains found in this study in the healthy newborn babies, indicates a commensal status of these strains possibly helping to inhibit colonization by pathogenic strains of the bacterium or other bacterial taxa. Some commensal and health beneficial strains of $E$. coli were reported to inhibit pathogenic $E$. coli strains and other taxa of pathogenic bacteria [76-80]. Although, small intestine of healthy babies actively produces lactase for hydrolyzing the milk sugar lactose for absorbing the produced monosaccharides glucose and galactose, some amount of lactose might pass in an undigested form to the babies' colon where it can be utilized by lactic acid and other lactose fermenting bacteria such as $E$. coli for a different net product. This ability of $E$. coli to utilize lactose might help for its early colonization of the neonates' colon. Thus, along with early colonization of the neonates' colon by lactic acid bacteria (LAB) [8], E. coli also has suitable nutritional conditions explaining their good ability for initial colonization of the neonates' colon where milk retaining lactose is the only diet provided to the neonates through either breast or formula feeding. This also support our conclusion that initial colonization of $E$. coli is postnatal where milk feeding of the newborn babies confers a viable nutritional requirement of this bacterium and many other health beneficial lactose fermenting taxa. The suitable nutritional conditions for these bacteria would help for fulfilling its health beneficial roles in such early stage of the neonates' body development. However, a defect in lactase praduntion in hahine ar adultac cmall intanctine, would lead to enhanced amount of lactose and hence Loading [MathJax]/jax/output/CommonHTML/jax.js 
enhanced fermentation by lactose fermenting bacteria such as $E$. coli leading to health troubles and lactose intolerance risk requiring feeding with lactose free milk or some other treatments. In healthy newborn babies, $E$. coli as a lactose fermenting bacterium would persist in such suitable nutritional conditions sustaining its early colonization of the colon for performing their health beneficial roles outlined in many aspects for healthy body development of the neonates. These suitable nutritional conditions for $E$. coli in the colon of newborn babies with milk as the only diet might explain the broad ability of $E$. coli strains for postnatal colonization of colon in newborn babies.

\section{Conclusions}

The absence of $E$. coli in meconium in all investigated neonates' subjects indicates possible antimicrobial properties present in it for protecting neonates from infection during delivery process where $E$. coli colonization occur after first-pass meconium by one day in case of normal birth and by 3 days in case of cesarean section surgical delivery. Further future studies would be of interest to explore the specific antimicrobial action and agents of meconium against inoculation of the neonates by various pathogenic and nonpathogenic bacteria in the vaginal microbiome. The initial colonization is thus a naturally controlled inoculation process for a healthy neonates' colon microbial ecosystem where $E$. coli start colonization postnatal in a healthy status of the neonates.

\section{Materials And Methods}

The occurrence of $E$. coli was investigated in first day meconium and subsequent days stool of healthy neonates in Almadinah Almunawarah, Kingdom of Saudi Arabia (KSA).

\section{Initial colonization of colon by E. coli in healthy neonates at the first week of their life.}

The initial colonization of colon by $E$. coli in healthy neonates at the first week of their life was followed by investigating its occurrence in meconium and subsequent 5 days stool of healthy newborn babies. Healthy neonates were chosen randomly of age one for obtaining first-pass meconium while subsequent days stool samples were obtained from babies of age 2 to 6 days old. A total of 120 newborn babies were investigated 20 neonate for each age ( 1 to 6 ) of which 10 for newborn babies of normal birth and 10 of surgical delivery in equal number of male and female neonates]. Occurrence of $E$. coli in meconium and subsequent days stool samples was conducted using EMB selective agar medium. Colony forming units (CFU) were determined by MPN (Most Probable Number) techniques [37]. The colonies of E. coli showing metallic green sheen was followed on the selective EMB agar where CFU of the bacterium was estimated from the lowest number of colonies in EMB agar plate in serial dilution of the inoculum followed by morphological and biochemical characterizations as outlined in Bergey's Manual [38]. A bacterial isolate from each of the healthy babies' subjects was further identification by phylogenetic analysis of $16 \mathrm{~S}$ rRNA encoding gene sequence. 
Promega Wizard Genomic DNA Purification Kits (Promega Corporation, Madison, Wisconsin, USA) was used to extract the genomic DNA of $E$. coli bacterial cultures according to the instructions kit manufacturer. The universal forward (27F:5-AGAG T TGATC $\left[\frac{A}{C}\right]$ TGGCTCAG - 3 and reverse 1492R:5- $\left.G\left[\frac{C}{T}\right] T A \mathbb{C} T G T A C G A C \mathrm{~T}-3\right)$ primers [39] were used to amplify a near-full length $16 \mathrm{~S}$ rRNA encoding gene by PCR using a reaction mixture $(25 \mu \mathrm{l})$ composed of $10 \times$ Taq buffer $(100 \mathrm{mM}$ Tris$\mathrm{HCl}, \mathrm{pH}$ 8) $2.5 \mu \mathrm{l} ; \mathrm{MgCl}_{2}(1.25 \mathrm{mM})$; dNTPs $(100 \mu \mathrm{M})$ (Invitrogen, Carlsbad, CA, USA); forward and reverse primer $(1.2 \mu \mathrm{M})$; Taq DNA polymerase (Invitrogen, USA) (0.5U), and template genomic DNA of about $5 \mathrm{ng}$. A Thermal Cycler (Model 2720; Applied Biosystems, Foster City, California, USA) was used for the PCR amplification that was performed with implemented PCR program $\left[95^{\circ} \mathrm{C}\right.$ for $5 \mathrm{~min}$ (initial denaturation), 35 amplification cycles $\left[94^{\circ} \mathrm{C}\right.$ for $1 \mathrm{~min}$ (denaturation), $56^{\circ} \mathrm{C}$ for $1 \mathrm{~min}$ (annealing), and $72^{\circ} \mathrm{C}$ for $1 \mathrm{~min}$ (extension)] followed by a final extension at $72^{\circ} \mathrm{C}$ for $10 \mathrm{~min}$.]. Agarose electrophoresis was used for analyzing the PCR amplification products on agarose $(1 \%)$ gels containing ethidium bromide $(5 \mu \mathrm{g} / \mathrm{mL})$ with [(Invitrogen, USA) 1 kb Plus DNA ladder] DNA size marker.

\section{Nucleotide sequence analysis and accession number}

The PCR products were purified and cycle sequenced at Macrogen Korea sequencing facility, (Seol, Korea). Direct cycle sequencing of the PCR purified product was conducted using same forward and reverse primers in both directions using automated florescent dye terminator sequencing method [40] at Macrogen Korea sequencing facility, (Seol, Korea) with 3730XL DNA Analyser (Applied Biosystems, CA, USA). The sequence reads were assembled and compared with the closest matches in GenBank by nucleotide-nucleotide BLAST search tool of the National Center for Biotechnology and Information (NCBI) server at www.ncbi.nlm.nih.gov/blast/Blast.cgi. Alignments of 16S rRNA gene sequences were performed by Clustal W1.83 XP [41]. The derived phylogenetic tree of the 16S rRNA gene sequences was constructed using neighbor-joining method [42] by MEGAX software [43]. An outgroup [Bacillus subtilis JCM 1465 (NR_113265)] was used.

\section{Nucleotide sequence accession number}

The 16S rRNA encoding gene partial nucleotide sequence of $E$. coli strains isolated from the stool of healthy male and female newborn babies of normal birth and cesarean section surgical delivery at the first week of their life was deposited in the GenBank nucleotide sequence NCBI database under accession numbers outlined in Supplementary Tables 2 to 5 .

\section{Declarations}

\section{Ethics approval and consent to participate}


The studies involving human participants were reviewed and approved by the Institutional Review Board (IRB) in Medina [Head of IRB Committee: Dr. Abduhameed Alsubhi]. All methods were performed in accordance with the relevant guidelines and regulations of the IRB in Medina, Saudi Arabia. Informed consent was obtained from parents for the collection of infant stools.

\section{Consent for publication}

Not applicable

\section{Availability of data and materials}

The datasets generated for this study can be found in the online repositories. The names of the repository/repositories and accession number(s) can be found in the article/supplementary material in Supplementary Tables 2 to 5 .

\section{Competing interests}

The authors declare that they have no competing interests.

\section{Author's contributions}

All authors listed have made a substantial, direct and intellectual contribution to the work, and approved it for publication. The authors have contributed equally to this work.

\section{Funding}

Not applicable

\section{Acknowledgements}

Not applicable

\section{References}

1. Gronlund, M. M., Arvilommi, H., Kero, P., Lehtonen, O. P., and Isolauri, E. Importance of intestinal colonisation in the maturation of humoral immunity in early infancy: a prospective follow up study of healthy infants aged 0-6 months. Arch. Dis. Child Fetal Neonatal Ed 2000;83:F186-192.

2. Macpherson, A. J. and Harris, N. L. Interactions between commensal intestinal bacteria and the immune system. Nat. Rev. Immunol. 2004;4:478-485.

3. Maccaferri, S., Biagi, E., and Brigidi, P. Metagenomics: key to human gut microbiota. Dig. Dis. 2011;29(6):525-30.

4. Donovan, S. M., Wang, M., Li, M., Friedberg, I., Schwartz, S. L., and Chapkin, R. S. Host-microbe interactions in the neonatal intestine: role of human milk oligosaccharides. Adv. Nutr. 
5. Haghshenas, B., Nami, Y., Abdullah, N., Radiah, D., Rosli, R., and Khosroushahi, A. Y. Anticancer impacts of potentially probiotic acetic acid bacteria isolated from traditional dairy microbiota. $L W T$ Food Sci. Technol. 2015;60:690-697.

6. Timmerman, H. M., Rutten, N., Boekhorst, J., Saulnier, D. M., Kortman, G., Contractor, N., Kullen, M., Floris, E., Harmsen, H., Vlieger, A. M., Kleerebezem, M., and Rijkers, G. T. Intestinal colonisation patterns in breastfed and formula-fed infants during the first 12 weeks of life reveal sequential microbiota signatures. Sci. rep. 2017;7(1):8327.

7. Stavropoulou E., and Bezirtzoglou, E. Human microbiota in aging and infection: A review. Crit. Rev. Food Sci. Nutr. 2019;59:537-545.

8. Al-Balawi, M., and Morsy, F. M. Enterococcus faecalis is a better competitor than other lactic acid bacteria in the initial colonization of colon of healthy newborn babies at first week of their life. Front. Microbiol. 2020;11:2017

9. Fanaro, S., Chierici, R., Guerrini, P., and Vigi, V. Intestinal microflora in early infancy: composition and development. Acta Paediatr. Suppl. 2003;91(441): 48-55.

10. Faith, J. J., Guruge, J. L., Charbonneau, M., Subramanian, S., Seedorf, H., Goodman, A. L., Clemente, J. C., Knight, R., Heath, A. C., Leibel, R. L., Rosenbaum, M., and Gordon, J. I. The long-term stability of the human gut microbiota. Science 2013;341:1237439.

11. Sommer, F., Anderson, J. M., Bharti, R., Raes, J., and Rosenstiel, P. The resilience of the intestinal microbiota influences health and disease. Nat. Rev. Microbiol. 2017;15:630-638.

12. Gosalbes, M. J., Llop, S., Valles, Y., Moya, A., Ballester, F., and Francino, M. P. Meconium microbiota types dominated by lactic acid or enteric bacteria are differentially associated with maternal eczema and respiratory problems in infants. Clin. Exp. Allergy 2013;43:198-211.

13. Hu, J., Nomura, Y., Bashir, A., Fernandez-Hernandez, H., Itzkowitz, S., Pei, Z., et al. Diversified microbiota of meconium is affected by maternal diabetes status. PLoS One 2013;8,e78257.

14. Moles, L., Gomez, M., Heilig, H., Bustos, G., Fuentes, S., de Vos, W., et al. Bacterial diversity in meconium of preterm neonates and evolution of their fecal microbiota during the first month of life. PLoS One 2013;8,e66986.

15. Ardissone, A. N., de la Cruz, D. M., Davis-Richardson, A. G., Rechcigl, K. T., Li, N., Drew, J. C., et al. Meconium microbiome analysis identifies bacteria correlated with premature birth. PLoS One 2014;9,e90784.

16. Hansen, R., Scott, K. P., Khan, S., Martin, J. C., Berry, S. H., Stevenson, M., et al. First-pass meconium samples from healthy term vaginally-delivered neonates: an analysis of the microbiota. PLoS One 2015;10,e0133320.

17. Nagpal, R., Tsuji, H., Takahashi, T., Kawashima, K., Nagata, S., Nomoto, K., et al. Sensitive quantitative analysis of the meconium bacterial microbiota in healthy term infants born vaginally or by cesarean section. Front. Microbiol. 2016;7:1997.

18. Stinson, L. F., Boyce, M. C., Payne, M. S. and Keelan, J. A. The not-so-sterile womb: Evidence that the Loading [MathJax]/jax/output/CommonHTML/jax.js r to birth. Front Microbio/ 2019;10:1124. 
19. Collado, M. C., Rautava, S., Aakko, J., Isolauri, E., and Salminen, S. Human gut colonisation may be initiated in utero by distinct microbial communities in the placenta and amniotic fluid. Sci. Rep. 2016;6:23129.

20. Urushiyama, D., Suda, W., Ohnishi, E., Araki, R., Kiyoshima, C., Kurakazu, M., et al. Microbiome profile of the amniotic fluid as a predictive biomarker of perinatal outcome. Sci. Rep. 2017;7:12171.

21. Verstraelen, H., Vilchez-Vargas, R., Desimpel, F., Jauregui, R., Vankeirsbilck, N., Weyers, S., et al. Characterisation of the human uterine microbiome in non-pregnant women through deep sequencing of the V1-2 region of the 16S rRNA gene. PeerJ 2016;4,e1602.

22. Bettelheim, K. A., and Lennox-King, S. M. The acquisition of Escherichia coli by new-born babies. Infection 1976;4(3):174-9.

23. Lennox-King, S. M., O'Farrell, S. M., Bettelheim, K. A., and Shooter, R. A. Colonization of caesarean section babies by Escherichia coli. Infection 1976;4(3):134-8.

24. Bezirtzoglou, E., and Romond, C. Occurrence of Enterobacteriaceae and E. coli in the intestine of the newborn by caesarean section. Acta Microbiol. Bulg. 1990;25:76-81.

25. Jang, J., Hur, H. G., Sadowsky, M. J., Byappanahalli, M. N., Yan, T., and Ishii, S. Environmental Escherichia coli: ecology and public health implications-a review. J. Appl. Microbiol. 2017;123(3):570-581.

26. Devane, M. L., Moriarty, E., Weaver, L., Cookson, A., \& Gilpin, B. Fecal indicator bacteria from environmental sources; strategies for identification to improve water quality monitoring. Water Res. 2020;185:116204.

27. Cools, P. The role of Escherichia coli in reproductive health: state of the art. Res. Microbiol. 2017;168:892-901

28. Miller, T. L., and Wolin, M. J. Fermentation by the human large intestine microbial community in an in vitro semi-continuous culture system. Appl. Environ. Microbiol. 1981;42:400-407

29. Englyst, H. N., Hay, S., and MacFarlane G. T. Polysaccharide breakdown by mixed populations of human faecal bacteria. Microbiol. Ecol. 1987;95:163-171

30. Macfarlane, G. T., and Macfarlane S. Fermentation in the human large intestine: its physiologic consequences and the potential contribution of prebiotics. J. Clin. Gastroenterol. 2011;45Suppl:S120-7.

31. Bennel, R., and Nord, C. E. Development of the faecal anaerobic microflora after Caesarean section and treatment with antibiotics in newborn infants. Infection 1987;15:332.

32. Abrahamsson, T. R., Sinkiewicz, G., Jakobsson, T., Fredrikson, M., and Björkstén, B. Probiotic lactobacilli in breast milk and infant stool in relation to oral intake during the first year of life. J. Pediatr. Gastroenterol. Nutr. 2009;49(3):349-354.

33. Penders, J., Thijs, C., Vink, C., Stelma, F. F., Snijders, B., Kummeling, I., van den Brandt, P. A., and Stobberingh, E. E. Factors influencing the composition of the intestinal microbiota in early infancy. Pediatrics 2006;118(2):511-521. 
34. Favier, C. F., Vaughan, E. E., De Vos, W. M., and Akkermans, A. D. L. Molecular monitoring of succession of bacterial communities in human neonates. Appl. Environ. Microbiol. 2002;68:219226.

35. Bezirtzoglou, E., Tsiotsias, A., and Welling, G. W. Microbiota profile in feces of breast- and formula-fed newborns by using fluorescence in situ hybridization (FISH). Anaerobe 2011;17:478-482.

36. Thursby, E., and Juge, N. Introduction to the human gut microbiota. Biochem. J. 2017;474(11):18231836.

37. MacFaddin, J. Media for isolation-cultivation-identification-maintenance of medical bacteria, Baltimore, Maryland: Williams and Wilkins; 1985;vol. 1.

38. Brenner, D. J., Krieg, N. R., Staley, J. T., and Garrity, G. M. Bergey’s manual of systematic bacteriology. New York, NY: Springer; 2005;p.492.

39. Lane, D. J. 16S/23S rRNA sequencing, In Nucleic acid Technique sin Bacterial Systematics, eds E. Stackebrandt and M. Goodfellow (NewYork, NY: John Wiley and Sons), 1991; p.115-175.

40. Sanger, F., Nicklen, S., and Coulson, A. R. DNA sequencing with chain-termination inhibitors. Proc. Natl. Acad. Sci. USA 1977;74:5463-5467.

41. Thompson, D., Gibson, J., Plewinak, F., Jeanmougin, F., and Higgins, G. The ClastalX windows interface: flexible strategies for multiple sequence alignment aided by quality analysis tools. Nuc. Acid Res. 1997;25:4867-4887.

42. Saitou, N., and Nei, M. The neighbor-joining method: a new method for reconstructing phylogenetic trees. Mol. Biol. Evol. 1987;4:406-425.

43. Kumar, S., Stecher, G., Li, M., Knyaz, C., and Tamura, K. MEGA X: Molecular evolutionary genetics analysis across computing platforms. Mol. Biol. Evol. 2018;35:1547-1549.

44. Hewitt, J. H., and Rigby, J. Effect of various milk feeds on numbers of Escherichia coli and Bidifobacterium in the stools of new-born infants. J. Hyg. (Lond). 1976;77(1):129-39.

45. Rotimi, V. O., and Duerden, B. I. The development of the bacterial flora in normal neonates. J. Med. Microbiol. 1981;14(1):51-62.

46. Rehbinder, E. M., Lodrup Carlsen, K. C., Staff, A. C., Angell, I. L., Landro, L., Hilde, K., et al. Is amniotic fluid of women with uncomplicated term pregnancies free of bacteria? Am. J. Obstet. Gynecol. 2018;219:289.e1-289.e12.

47. Lifschitz, H. C. The role of colonic flora in infants. Chapter 20 in R.R. Watson et al., (eds.), Nutrition in Infancy, Nutrition and Health, DOI 10.1007/978-1-62703-254-4\$420, Springer Science plus Business Media New York 2013;Vol. 2.

48. Sáez-López, E., Cossa, A., Benmessaoud, R., Madrid, L., Moraleda, C., Villanueva, S., Tligui, H., Moiane, B., Alami, H., Massora, S., Bezad, R., Mandomando, I., Bosch, J., Vila, J., Bassat, Q., and Soto, S. M. Characterization of vaginal Escherichia coli isolated from pregnant women in two different African sites. PLOS ONE 2016;11(7):e0158695 
49. Dobbler, P., Mai, V., Procianoy, R. S., Silveira, R. C., Corso, A. L., and Roesch, L. F. W. The vaginal microbial communities of healthy expectant Brazilian mothers and its correlation with the newborn's gut colonization. World. J. Microbiol. Biotechnol. 2019;35:159

50. Dominguez-Bello, M. G., Costello, E. K., Contreras, M., Magris, M., Hidalgo, G., Fierer, N., and Knight, R. Delivery mode shapes the acquisition and structure of the initial microbiota across multiple body habitats in newborns. Proc. Natl. Acad. Sci. 2010;107:11971-11975.

51. Milani, C., Duranti, S., Bottacini, F., Casey, E., Turroni, F., Mahony, J., Belzer, C., Delgado Palacio, S., Arboleya Montes, S., Mancabelli, L., Lugli, G. A., Rodriguez, J. M., Bode, L., de Vos, W., Gueimonde, M., Margolles, A., van Sinderen, D., Ventura, M. The first microbial colonizers of the human gut: composition, activities, and health implications of the infant gut microbiota. Microbiol. Mol. Biol. Rev. 2017;81:e00036-17.

52. Nowrouzian, F., Hesselmar, B., Saalman, R., Strannegård, I-L., Åberg, N., Wold, A. E., and Adlerberth, I. Escherichia coli in infants' intestinal microflora: colonization rate, strain turnover, and virulence gene carriage. Pediatr. Res. 2003;54:8-14.

53. Wall, R., Ross, R. P., Ryan, C. A., Hussey, S., Murphy, B., Fitzgerald, G. F., and Stanton, C. Role of gut microbiota in early infant development. Clin. Med. Pediatr. 2009;3:45-54.

54. Fernández, L., Langa, S., Martín, V., Maldonado, A., Jiménez, E., Martín, R., and Rodríguez, J. M. The human milk microbiota: origin and potential roles in health and disease. Pharmacol. Res. 2013:69:110

55. Friedman, E. S., Bittinger, K., Esipova, T. V., Hou, L., Chau, L., Jiang, J., Mesaros, C., Lund, P. J., Liang, X., FitzGerald, G. A., Goulian, M., Lee, D., Garcia, B. A., Blair, I. A., Vinogradov, S. A., and Wu, G. D. Microbes vs. chemistry in the origin of the anaerobic gut lumen. Proc. Natl. Acad. Sci. USA 2018;115(16):4170-4175.

56. Guest, J. R., and Shaw, D. J. Molecular cloning of menaquinone biosynthetic genes of Escherichia coli K12. Mol. Gen. Genet. 1981;181(3):379-383.

57. Bentley, R., and Meganathan, R. Biosynthesis of vitamin K (menaquinone) in bacteria. Microbiol. Rev. 1982;46(3):241-80.

58. Marley, M. G., Meganathan, R., and Bentley, R. Menaquinone (vitamin K2) biosynthesis in Escherichia coli: synthesis of o-succinylbenzoate does not require the decarboxylase activity of the ketoglutarate dehydrogenase complex. Biochemistry 1986;25(6):1304-1307.

59. Bhattacharyya, D. K., Kwon, O., and Meganathan, R. Vitamin $\mathrm{K}_{2}$ (menaquinone) biosynthesis in Escherichia coli: evidence for the presence of an essential histidine residue in o-succinylbenzoyl coenzyme A synthetase. J. Bacteriol. 1997;179:6061-6065.

60. Jiang, M., Cao, Y., Guo, Z. F., Chen, M., Chen, X., and Guo, Z. Menaquinone biosynthesis in Escherichia coli: identification of 2-succinyl-5-enolpyruvyl-6-hydroxy-3-cyclohexene-1-carboxylate as a novel intermediate and re-evaluation of MenD activity. Biochemistry 2007;46(38):10979-10989.

61. Jiang, M., Chen, X. L., Guo, Z. F., Cao, Y., Chen, M. J., and Guo, Z. H. Identification and characterization Loading [MathJax]/jax/output/CommonHTML/jax.js :lohexadiene-1-carboxylate synthase in the menaquinone 
biosynthesis of Escherichia coli. Biochemistry 2008;47(11):3426-34

62. Leonardi, R., Fairhurst, S. A., Kriek, M., Lowe, D. J., and Roach, P. L. Thiamine biosynthesis in Escherichia coli: isolation and initial characterization of the ThiGH complex. FEBS Lett. 2003; 539(13):95-99.

63. Leonardi, R., and Roach, P. L. Thiamine biosynthesis in Escherichia coli: in vitro reconstitution of the thiazole synthase activity. J. Biol. Chem. 2004;279(17):17054-17062.

64. Kriek, M., Martins, F., Challand, M. R., Croft, A., and Roach, P. L. Thiamine biosynthesis in Escherichia coli: identification of the intermediate and by-product derived from tyrosine. Angew. Chem. Int. Ed. Engl. 2007:46(48):9223-9226.

65. Du, Q., Wang, H., and Xie, J. Thiamin (vitamin B1) biosynthesis and regulation: a rich source of antimicrobial drug targets?. Int. J. Biol. Sci. 2011:7(1):41-52.

66. Kaper, J. B., Nataro, J. P., and Mobley, H. L. Pathogenic Escherichia coli. Nat. Rev. Microbiol. 2004;2(2):123-140.

67. Navarro-Garcia, F. Escherichia coli 0104:H4 pathogenesis: An enteroaggregative E. coli/Shiga toxinproducing E. coli explosive cocktail of high virulence. Microbiol. Spectr. 2014;2(6), 10.1128/microbiolspec.EHEC-0008-2013.

68. Gao, Y. D., Zhao, Y., and Huang, J. Metabolic modeling of common Escherichia coli strains in human gut microbiome. Biomed. Res. Int. 2014;694967.

69. Delmas, J., Dalmasso, G., and Bonnet, R. Escherichia coli: The good, the bad and the ugly. Clin. Microbiol. 2015;4:195.

70. Grozdanov, L., Raasch, C., Schulze, J., Sonnenborn, U., Gottschalk, G., Hacker, J., and Dobrindt, U. Analysis of the genome structure of the nonpathogenic probiotic Escherichia colistrain Nissle 1917. J. Bacteriol. 2004;186:5432-41.

71. Westendorf, A. M., Gunzer, F., Deppenmeier, S., Tapadar, D., Hunger, J. K., Schmidt, M. A., Buer, J., and Bruder, D. Intestinal immunity of Escherichia coli NISSLE 1917: a safe carrier for therapeutic molecules. FEMS Immunol. Med. Microbiol. 2005;43:373-84.

72. Xia, P., Zhu, J., and Zhu, G. Escherichia coli Nissle 1917 as safe vehicles for intestinal immune targeted therapy-A review. Acta Microbiol. Sin. 2013;53: 538-544.

73. Mohsin, M., Guenther, S., Schierack, P., Tedin, K., and Wieler, L. H. Probiotic Escherichia coli Nissle 1917 reduces growth, Shiga toxin expression, release and thus cytotoxicity of enterohemorrhagic Escherichia coli. Int. J. Med. Microbiol. 2015;305(1):20-26.

74. Sonnenborn, U. Escherichia coli strain Nissle 1917-from bench to bedside and back: history of a special Escherichia coli strain with probiotic properties. FEMS Microbiol. Lett. 2016;363(19):fnw212.

75. Wassenaar, T. M. Insights from 100 years of research with probiotic E. coli. Eur. J. Microbiol. Immunol. (Bp) 2016;6:147-161.

76. Hudault, S., Guignot, J., and Servin, A. L. Escherichia coli strains colonising the gastrointestinal tract protect qermfree mice aqainst Salmonella typhimurium infection. Gut 2001;49(1):47-55.

Loading [MathJax]/jax/output/CommonHTML/jax.js 
77. Reissbrodt, R., Hammes, W. P., dal Bello, F., Prager, R., Fruth, A., Hantke, K., Rakin, A., Starcic-Erjavec, M., and Williams, P. H. Inhibition of growth of Shiga toxin-producing Escherichia coli by nonpathogenic Escherichia coli. FEMS Microbiol. Lett. 2009;290:62-69.

78. Maltby, R., Leatham-Jensen, M. P., Gibson, T., Cohen, P. S., and Conway, T. Nutritional basis for colonization resistance by human commensal Escherichia coli strains HS and Nissle 1917 against $E$. coli 0157:H7 in the mouse intestine. PLoS One 2013;8:e53957.

79. Rund, S. A., Rohde, H., Sonnenborn, U., and Oelschlaeger, T. A. Antagonistic effects of probiotic Escherichia coli Nissle 1917 on EHEC strains of serotype 0104:H4 and 0157:H7. Int. J. Med. Microbiol. 2013;303(1):1-8.

80. Christofi, T., Panayidou, S., Dieronitou, I., Michael, C., and Apidianakis, Y. Metabolic output defines Escherichia coli as a health-promoting microbe against intestinal Pseudomonas aeruginosa. Sci. Rep. 2019;9:14463.

\section{Figures}

Fig. 1
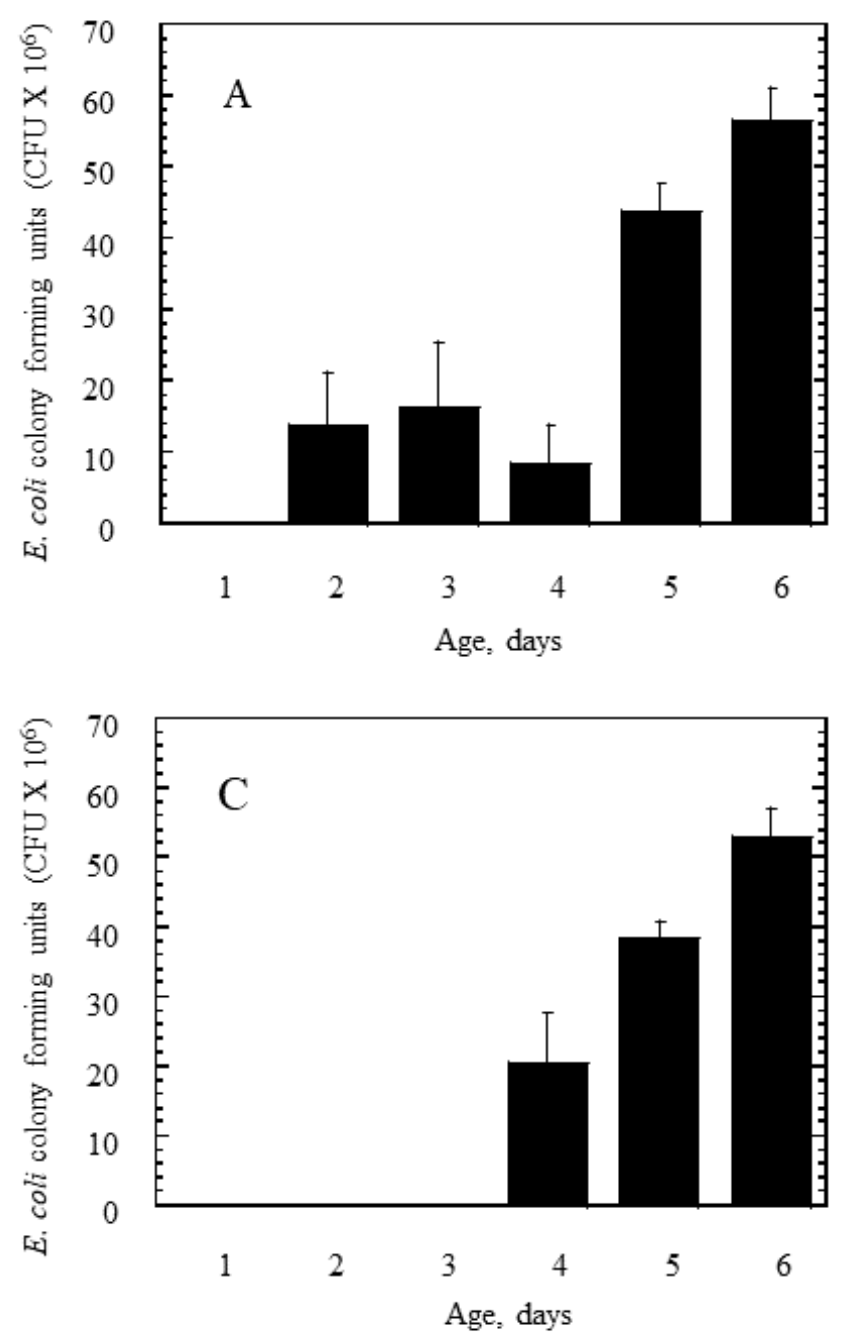
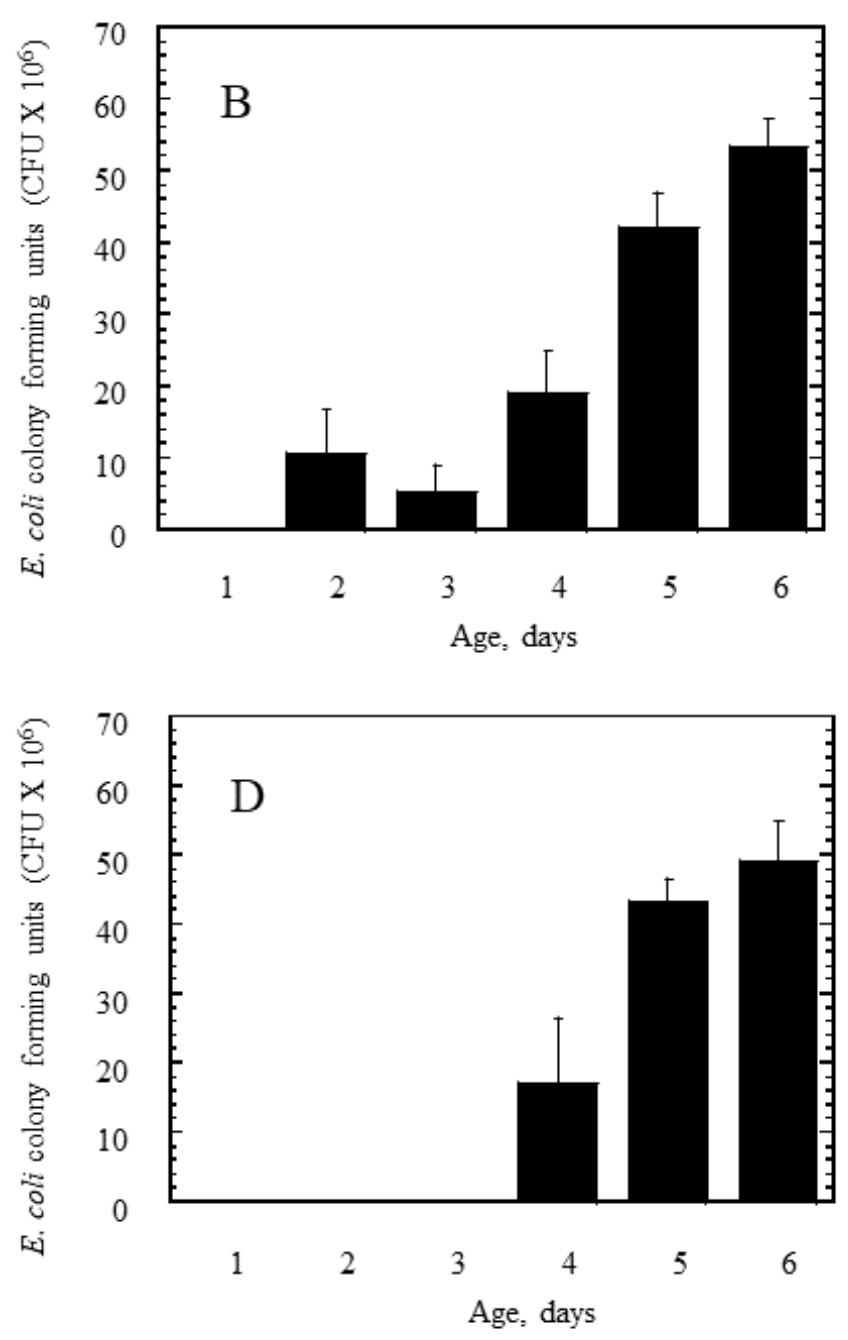
Figure 1

Escherichia coli colony forming units (CFU $\times 106$ ) occurrence determination in first day meconium and subsequent days stool of normal birth male neonates (Panel A), normal birth female neonates (Panel B), cesarean section surgical delivery male neonates (Panel $\mathrm{C}$ ) and cesarean section surgical delivery female neonates (Panel D). Mean values and standard errors are of 5 independent subject babies randomly selected in each age days.

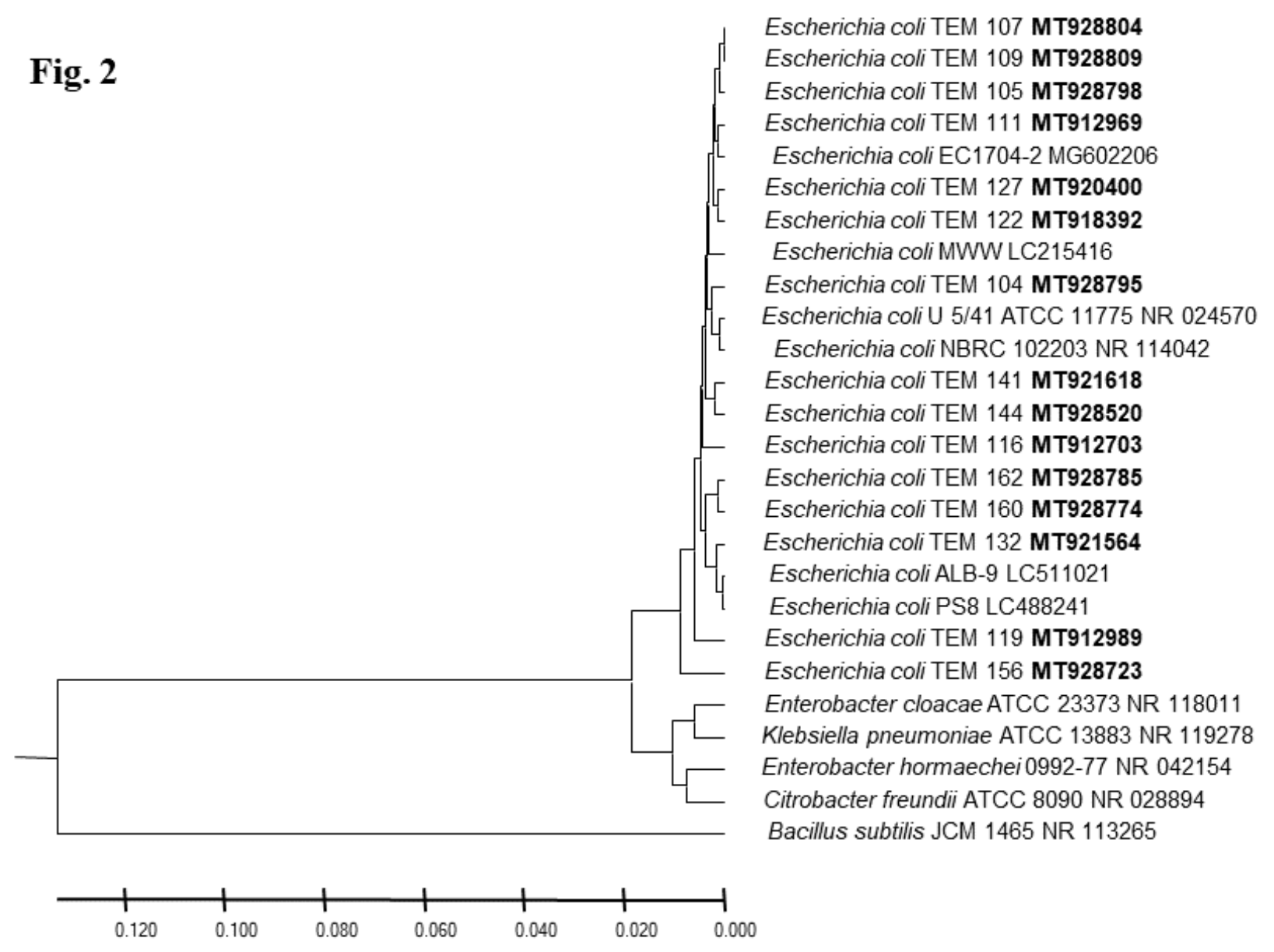

Figure 2

Phylogenetic analysis of strains 16S rRNA gene of Escherichia coli isolated from stool of healthy male neonates of normal birth by vaginal delivery at the first week of their life. A phylogenetic tree of isolated Escherichia coli strains showing relationship with the closest bacterial neighbor strains from NCBI. The accession numbers of isolated Escherichia coli strains is shown in bold. The neighbor-joining tree of isolated Escherichia coli strains and other bacterial strains was determined using a near-full length gene sequences of $16 \mathrm{~S}$ rRNA and the frequency filter in the MEGX software analysis package. An out-group 
Bacillus subtilis JCM 1465 (accession number; NR_113265) was used. A scale bar section indicates $2 \%$ estimated difference in sequence. The NCBI database accession numbers of each strain are shown.

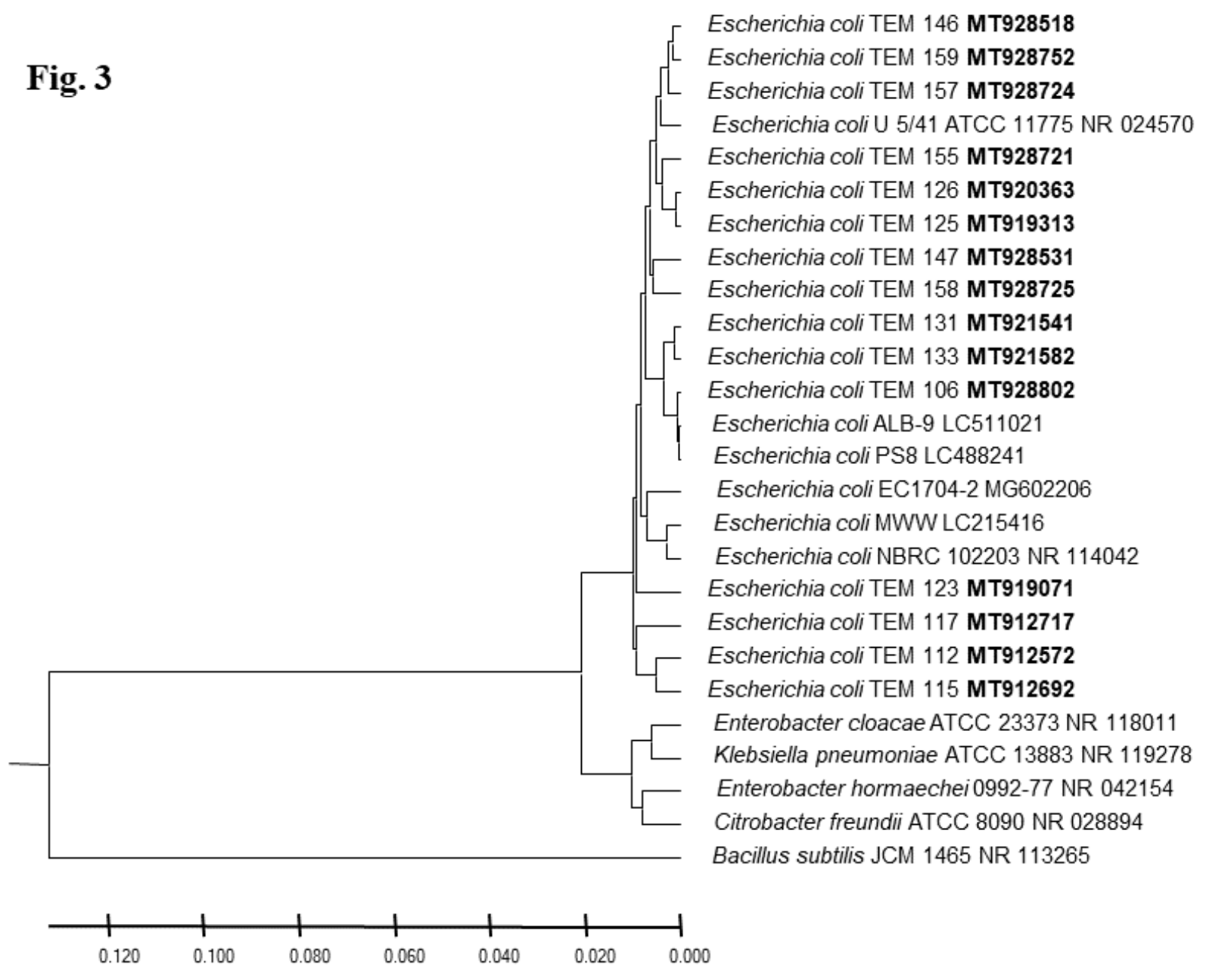

Figure 3

Phylogenetic analysis of strains 16S rRNA gene of Escherichia coli isolated from stool of healthy female neonates of normal birth by vaginal delivery at the first week of their life. A phylogenetic tree of isolated Escherichia coli strains showing relationship with the closest bacterial neighbor strains from NCBI. The accession numbers of isolated Escherichia coli strains is shown in bold. The neighbor-joining tree of isolated Escherichia coli strains and other bacterial strains was determined using a near-full length gene sequences of $16 \mathrm{~S}$ rRNA and the frequency filter in the MEGX software analysis package. An out-group Bacillus subtilis JCM 1465 (accession number; NR_113265) was used. A scale bar section indicates $2 \%$ estimated difference in sequence. The NCBI database accession numbers of each strain are shown. 


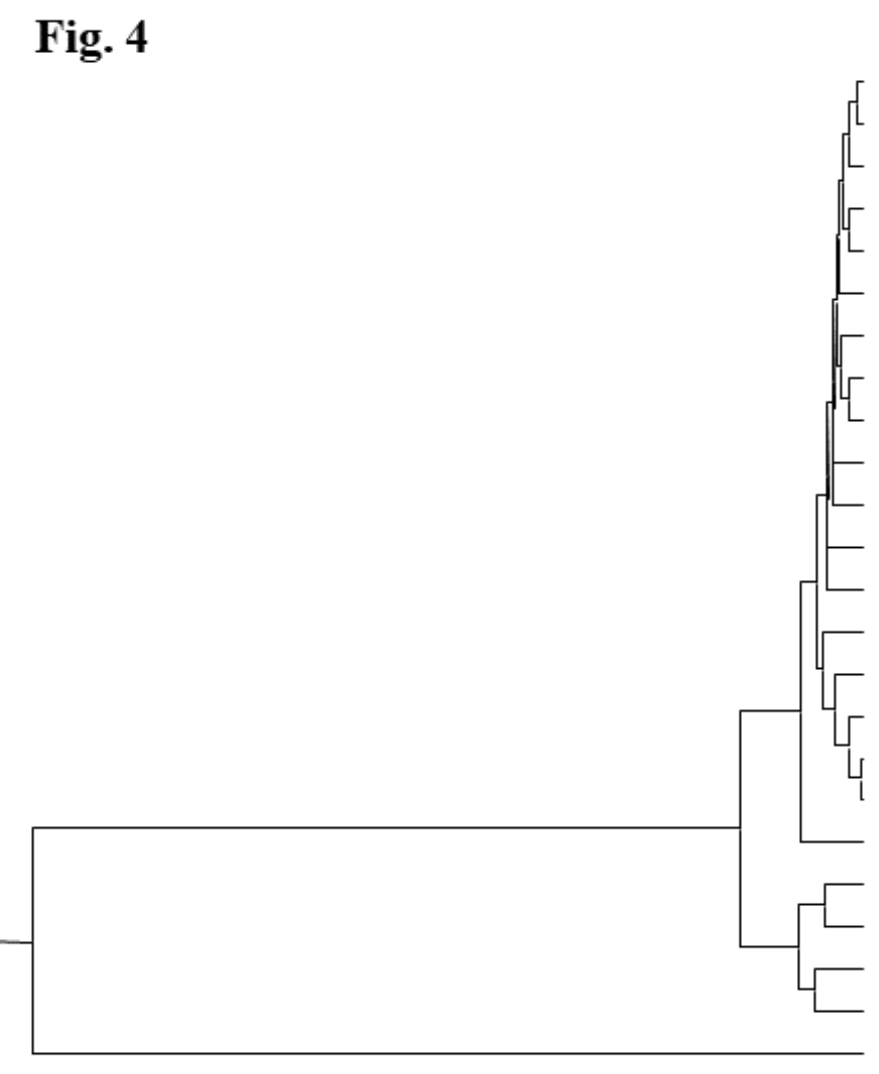

Escherichia coli U 5/41 ATCC 11775 NR 024570

[ Escherichia coli NBRC 102203 NR 114042

- Escherichia coli TEM 164 MT928786

Escherichia coli TEM 135 MT921593

- Escherichia coli TEM 154 MT928720

Escherichia coli TEM 153 MT928717

Escherichia coli MWW LC215416

Escherichia coli TEM 118 MT912740

Escherichia coli EC1704-2 MG602206

Escherichia coli TEM 134 MT921592

Escherichia coli TEM 143 MT928123

Escherichia coli TEM 148 MT928713

Escherichia coli TEM 128 MT921145

Escherichia coli TEM 161 MT928775

Escherichia coli TEM 129 MT921164

Escherichia coli TEM 130 MT921414

Escherichia coli ALB-9 LC511021

Escherichia coli PS8 LC488241

Escherichia coli TEM 101 MT102883

Enterobacter cloacae ATCC 23373 NR 118011

Klebsiella pneumoniae ATCC 13883 NR 119278

Enterobacter hormaechei 0992-77 NR 042154

Citrobacter freundii ATCC 8090 NR 028894

Bacillus subtilis JCM 1465 NR 113265

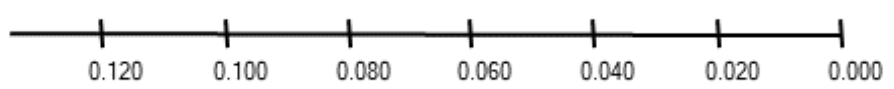

Figure 4

Phylogenetic analysis of strains 16S rRNA gene of Escherichia coli isolated from stool of healthy male neonates of cesarean section surgical delivery at the first week of their life. A phylogenetic tree of isolated Escherichia coli strains showing relationship with the closest bacterial neighbor strains from NCBI. The accession numbers of isolated Escherichia coli strains is shown in bold. The neighbor-joining tree of isolated Escherichia coli strains and other bacterial strains was determined using a near-full length gene sequences of $16 \mathrm{~S}$ rRNA and the frequency filter in the MEGX software analysis package. An out-group Bacillus subtilis JCM 1465 (accession number; NR_113265) was used. A scale bar section indicates $2 \%$ estimated difference in sequence. The NCBI database accession numbers of each strain are shown. 


\section{Fig. 5}

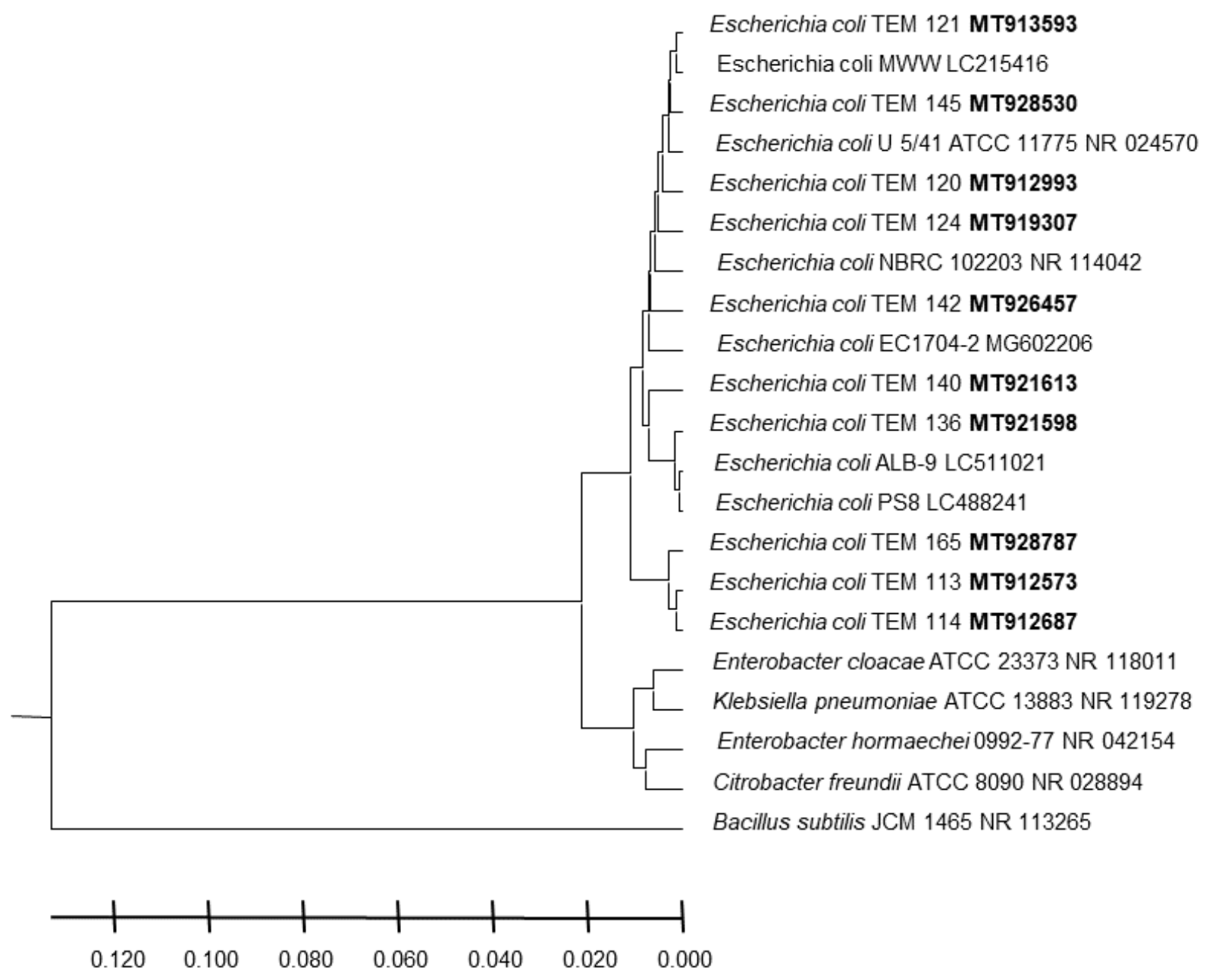

\section{Figure 5}

Phylogenetic analysis of strains 16S rRNA gene of Escherichia coli isolated from stool of healthy female neonates of cesarean section surgical delivery at the first week of their life. A phylogenetic tree of isolated Escherichia coli strains showing relationship with the closest bacterial neighbor strains from NCBI. The accession numbers of isolated Escherichia coli strains is shown in bold. The neighbor-joining tree of isolated Escherichia coli strains and other bacterial strains was determined using a near-full length gene sequences of $16 \mathrm{~S}$ rRNA and the frequency filter in the MEGX software analysis package. An out-group Bacillus subtilis JCM 1465 (accession number; NR_113265) was used. A scale bar section indicates $2 \%$ estimated difference in sequence. The NCBI database accession numbers of each strain are shown.

\section{Supplementary Files}

This is a list of supplementary files associated with this preprint. Click to download. 